\title{
HEIGHT STRUCTURE AND SPATIAL PATTERN OF FIVE TROPICAL TREE SPECIES IN TWO SEASONAL SEMIDECIDUOUS FOREST FRAGMENTS WITH DIFFERENT CONSERVATION HISTORIES ${ }^{1}$
}

\author{
Diego Resende Rodrigues ${ }^{2 *}$, Yves Rafael Bovolenta ${ }^{2}$ José Antonio Pimenta $^{3}$ and Edmilson Bianchini ${ }^{3}$
}

\footnotetext{
${ }^{1}$ Received on 18.05.2013 accepted for publication on 18.12.2015.

${ }^{2}$ Universidade Estadual de Londrina, Programa de Pós-Graduação em Ciências Biológicas, Londrina, Paraná - Brasil. E-mail: <diegorr2001@yahoo.com.br>and<yvesrafael@yahoo.com.br>.

${ }^{3}$ Universidade Estadual de Londrina, Centro de Ciências Biológicas, Londrina, Paraná - Brasil. E-mail: <pimenta@uel.br $>$ and $<$ bianchi@uel.br $>$.

*Corresponding author.
}

\begin{abstract}
Anthropogenic disturbances in forests modify survival conditions and development of plants, which has direct effect on the height and spatial structure of tree populations. This study aimed to compare the height structure and spatial pattern of five tree species in two distinct fragments of seasonal semideciduous forest with different histories of conservation. We studied shade-intolerant (Astronium graveolens Jacq., Gallesia integrifolia (Spreng.) Harms) and shade-tolerant species (Chrysophyllum gonocarpum (Mart. \& Eichler ex Miq.) Engl., Euterpe edulis Mart. and Holocalyx balansae Micheli). Sixty plots of $100 \mathrm{~m}^{2}(10 \mathrm{~m} \times 10 \mathrm{~m})$ were allocated, being 30 contiguous plots in each fragment. All individuals of five species were marked, assessed for total height data and mapped using Cartesian coordinates. We observed differences in height structure between fragments. All populations had a random spatial pattern, except to H. balansae in the less conserved fragment and E. edulis in the conserved fragment that showed a clumped spatial pattern. There were evidences of forest regeneration due to the establishment of shade-tolerant species in less conserved fragment and coexistence of functional groups in both fragments. The height structure and spatial pattern analyses indicating that anthropogenic exploitation changed the environment and population structure in the less conserved area when compared to conserved area. The anthropic exploitation was ceased few years ago, so it is expected that the less conserved fragment reach the stability of an old-growth forest.
\end{abstract}

Keywords: Size structure; Spatial pattern; Tropical forest.

\section{ESTRUTURA DE ALTURA E DISTRIBUIÇÃO ESPACIAL DE CINCO ESPÉCIES ARBÓREAS EM DOIS FRAGMENTOS DE FLORESTA ESTACIONAL SEMIDECIDUAL COM DIFERENTES HISTÓRICOS DE CONSERVAÇÃO}

\begin{abstract}
RESUMO-Os distúrbios causados em florestas pela ação do homem alteram as condições de sobrevivência e desenvolvimento de plantas, tendo efeito direto na estrutura populacional das espécies. O presente estudo objetivou comparar as estruturas de altura e espacial de cinco espécies arbóreas em dois fragmentos de floresta estacional semidecidual, com diferentes históricos de conservação. Foram estudadas espécies intolerantes (Astronium graveolens Jacq. e Gallesia integrifolia (Spreng.) Harms) e as tolerante à sombra (Chrysophyllum gonocarpum (Mart. \& Eichler ex Miq.) Engl., Euterpe edulis Mart. e Holocalyx balansae Micheli). Foram alocadas 60 parcelas de $100 \mathrm{~m}^{2}(10 \mathrm{~m} \times 10 \mathrm{~m})$, sendo 30 parcelas contíguas em cada fragmento. Todos os indivíduos, das cinco espécies, contidos nas áreas foram marcados, medidos a altura e mapeados com o uso de coordenadas cartesianas. Foram observadas diferenças na distribuição de altura, entre as áreas com diferentes históricos de conservação. Todas as populações apresentaram distribuição aleatória, com exceção de $\boldsymbol{H}$. balansae na área menos conservada e $\boldsymbol{E}$. edulis na área sem histórico de perturbação, que apresentaram distribuição agregada. Há indícios de regeneração florestal, devido ao estabelecimento de
\end{abstract}


espécies tolerantes à sombra na área menos conservada e a coexistência de grupos funcionais em ambas as áreas. A análise dos resultados da estrutura de altura e espacial demonstrou indicativos de que a exploração antrópica alterou o ambiente e a estrutura populacional das espécies da área menos conservada, quando comparado com a área mais conservada. Como não há mais exploração antrópica, espera-se que ofragmento menos conservado atinja a estabilidade de uma floresta madura.

Palavras-chave: Estrutura de tamanho; Padrão espacial; Floresta tropical.

\section{INTRODUCTION}

Disturbances in forests, as selective logging, change the habitat, especially with regard to moisture, temperature and luminosity in comparison with preserved habitats, affecting survival and development of plants (GUARIGUATA; OSTERTAG, 2001; LIEBSCH et al., 2008; BURTON et al., 2009). These microclimatic alterations cause changes in germination, growth and plant reproduction, with direct effect on size structure and spatial pattern of these populations (GETZIN et al., 2008; TSINGALIA, 2010; SAHU et al., 2012; SUZUKI et al., 2012). Currently, tropical forests are fragmented due to human action, and the remnants of various sizes are in process of secondary succession (SOUZA et al., 2002; MARANGON et al., 2008).

The knowledge about population structure can help the understanding of species response to habitat changes caused by disturbances (BRUNA; KRESS, 2002; GAMA et al., 2002; ANDRADE et al., 2007; DE CROP et al., 2012). The structures of plant populations are influenced by biotic and abiotic factors to which their members and in some cases their ancestors were exposed (HUTCHINGS, 1997). These structures can indicate the occurrence of forest regeneration (AGREN; ZACKRISSON, 1990).

Comparison of size distributions in different areas can help to reveal characteristics of life histories, as well as their responses to human impact (SOUZA, 2007). According to Wright et al. (2003), size distributions with many large individuals and relatively rare small individuals characterize shade-intolerant species with high fecundity, rapid sapling growth, and high mortality of seeds, seedlings, and saplings. Size distributions with many small individuals and relatively rare large individuals characterize shade-tolerant species with lower fecundity, slower sapling growth, and lower mortality of seeds, seedlings, and saplings.

This study aims to compare the height structure and spatial pattern of five tree species in two seasonal semideciduous forest fragments with different conservation histories. We hypothesized that size structure and spatial pattern of species are different between fragments. As shade-intolerant species require light to regeneration, they would probably have a higher abundance and a less clustered spatial pattern in a lighter fragment because of anthropic perturbation.

\section{MATERIALAND METHODS}

The study was carried out in two seasonal semideciduous forest fragments in Paraná state, Brazil: São Francisco Forest State Park (SFFSP) and Godoy Forest State Park (GFSP). The SFFSP $\left(023^{\circ} 15^{\prime}\right.$ 'S $050^{\circ} 45^{\prime} \mathrm{W}$ - center of fragment) has about 840 ha, with history of human impact and high degree of degradation in some parts of fragment, especially selective logging of Aspisdosperma polyneuron Müll. Arg. and other species, extraction of palm (Euterpe edulis Mart.), illegal hunting and fire occurrence about 40 years ago in some part of fragment (TOMÉ et al., 1999). These anthropogenic interferences ceased in 1994 when the area was transformed in a conservation unit. The GFSP $\left(023^{\circ} 09^{\prime} \mathrm{S}\right.$ $050^{\circ} 34^{\prime} \mathrm{W}$ - center of fragment) has $650 \mathrm{ha}$, and it is a conserved forest without anthropic interference (SILVEIRA, 2006). The region's climate, according to Köppen, is characterized as Cfa, with average rainfall between 1200-1400 mm in SFFSP and 1400-1600 mm in GFSP, both distributed unevenly throughout the year (IAPAR, 2000). The predominant soils in SFFSP are Eutroferric Red Latosol and Eutroferric Red Nitosol, with inclusions of Chernosols and Gleysols (EMBRAPA, 1999) and Eutroferric Red Latosol and Red Nitosol Eutroferric in association with Entisols in GFSP (EMBRAPA, 1999), all of them considered as soils with high fertility.

The species were selected by the importance value index (IV) (BROWER; ZAR, 1984) in phytosociological inventory in SFFSP (TOMÉ et al., 1999) and GFSP (SOARES-SILVA; BARROSO, 1992). The selected species are common in fragments of seasonal semideciduous forest of the region (DIAS et al., 2002). Species were divided into shade-intolerant species (Astronium 
graveolens Jacq.; Gallesia integrifolia (Spreng.) Harms) and shade-tolerant species (Chrysophyllum gonocarpum (Mart. \& Eichler ex Miq.) Engl.; Euterpe edulis Mart.; Holocalyx balansae Micheli) based in the literature (SWAINE; WHITMORE, 1988; SOARES-SILVA; BARROSO, 1992; TOMÉ et al., 1999; SILVA; SOARESSILVA, 2000; LORENZI, 2002; ZAMAetal., 2012). Euterpe edulis was selected for the study, since it is a typical species of this forest formation.

The study was conducted in 30 plots (sampling areas) in each fragment, with similar physiognomy and slope. These areas were divided into $10 \mathrm{~m}$ x $10 \mathrm{~m}$ plots $\left(100 \mathrm{~m}^{2}\right)$ allocated contiguously, subdivided into 120 subplots of $25 \mathrm{~m}^{2}(5 \mathrm{~m} \mathrm{x} 5 \mathrm{~m})$, forming a rectangle of $50 \mathrm{~m} \times 60 \mathrm{~m}\left(3000 \mathrm{~m}^{2}\right)$. All individuals of five species, even seedlings, included in these areas were marked and their height was measured. In trees smaller than $3 \mathrm{~m}$, the height was calculated using a common measuring tape whereas in trees larger than $3 \mathrm{~m}$, the height was calculated using a digital laser tape measure. When it was not possible the height was visually estimated using a measuring tape as a reference.

To compare the height structure of populations among areas, individuals were divided into height classes. Kolmogorov-Smirnov test $(\alpha \leq 0.05)$ (ZAR, 1984) was used in order to evaluate the differences of height structure among areas.

We used the number of individuals for each $5 \times$ $5 \mathrm{~m}$ subplot and subplot center coordinates to determine the spatial pattern of each species. The spatial pattern was analyzed using Moran's $I$ spatial autocorrelation coefficient (LEGENDRE; FORTIN, 1989) calculated for 14 distance classes. We tested the null hypothesis that the $I$ coefficient, at each distance class, is not significantly different from zero, indicating randomness (LEGENDRE; FORTIN, 1989). A spatial correlogram was built based on $I$ values as a function of the distance classes, and its significance was tested using Bonferroni criterion (ODEN, 1984).

To evaluate if there was difference in luminosity among areas, the cover index (CI) was calculated using a spherical densiometer (LEMMON, 1956) and measurements taken at breast level. The CI was taken in July 2010 at an interval of one day between areas. The CI was evaluated for each plot and represents the average value of four measurements. Each measurement was taken with densiometer toward to each corner of the plot. Furthermore, we calculated the average of CI for each sample area. We compared the CI average of the each sample area by t-test (ZAR, 1984).

To correlate the spatial pattern with CI, it was necessary to remove the "spatial" effect. The partial Mantel test (SMOUSE et al., 1986) was used to remove spatial autocorrelation.

The autocorrelation analyses and partial Mantel tests were performed with Passage 2 Software (ROSENBERG, 2001).

\section{RESULTS}

We sampled 601 individuals of shade-intolerant species in the two areas, being 506 in SFFSP and 95 in GFSP (Table 1). The two shade-intolerant species were more abundant in SFFSP.

The height structure of $A$. graveolens and $G$. integrifolia differed among fragments (Table 1), probably due to lower number of individuals in the first height classes in GFSP (Figure 1).

Astronium graveolens showed a height structure similar to a J-reverse pattern in SFFSP, characterized by having a higher number of individuals in the smaller size classes (84.5\% at first two classes), and decreasing at the last height classes. In GFSP, there was a notable reduction in the number of individuals in the first two classes $(37.5 \%)$ and we did not observe individuals over $12 \mathrm{~m}$ of height (Figure 1).

The height structure of G. integrifolia in SFFSP was similar a J-reverse pattern too, with a higher number of individuals in the first two height classes (66\%), but with an increase of individuals in the last two height classes (20\%). In GFSP, 93.5\% of individuals (29) were found in the first two classes, and only $6.5 \%$ in the last class $(>8 \mathrm{~m})$ (Figure 1), with absence of individuals in other height classes.

The correlogram analysis suggests random spatial pattern in both areas for both species (Figure 2).

The cover index was higher in GFSP $(94 \% \pm 0.36)$ than in SFFSP $(83.5 \% \pm 0.85)$. Therefore, SFFSP showed an opener and more illuminated canopy. The spatial pattern of the two shade-intolerant species was not correlated with luminosity in both fragments $(\mathrm{P}>0.05)$.

Revista Árvore, Viçosa-MG, v.40, n.3, p.395-405, 2016

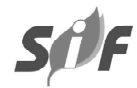


Table 1 - Comparison of height structures of populations using Kolmogorov-Smirnov test (D) and numbers of individuals (n) of five species in São Francisco Forest State Park (SFFSP) and Godoy Forest State Park (GFSP), Parana State, Brazil.

Tabela 1 - Comparações das estruturas de altura pelo teste de Kolmogorov-Smirnov (D) e números de indivíduos (n) de cinco espécies no Parque Estadual Mata São Francisco (SFFSP) e Parque Estadual Mata dos Godoy (GFSP), Paraná, Brasil.

\begin{tabular}{|c|c|c|c|c|c|}
\hline & & \multicolumn{2}{|c|}{ Height } & SFFSP & GFSP \\
\hline & & $\mathrm{D}$ & $\mathrm{P}$ & \multicolumn{2}{|c|}{$\mathrm{N}$} \\
\hline & Shade-intolerant species & & & 506 & 95 \\
\hline $\mathrm{SFFSP} \times \mathrm{GFSP}$ & Astronium graveolens & 0,470 & $<0,0001$ & 387 & 64 \\
\hline \multirow[t]{2}{*}{$\mathrm{SFFSP} \times$ GFSP } & Gallesia integrifolia & 0,595 & $<0,0001$ & 119 & 31 \\
\hline & Shade-tolerant species & & & 994 & 3205 \\
\hline $\mathrm{SFFSP} \times \mathrm{GFSP}$ & Chrysophyllum gonocarpum & 0,379 & $<0,0001$ & 159 & 414 \\
\hline $\mathrm{SFFSP} \times \mathrm{GFSP}$ & Euterpe edulis & 0,119 & $<0,0001$ & 735 & 2081 \\
\hline SFFSP $\times$ GFSP & Holocalyx balansae & 0,402 & $<0,0001$ & 100 & 710 \\
\hline
\end{tabular}
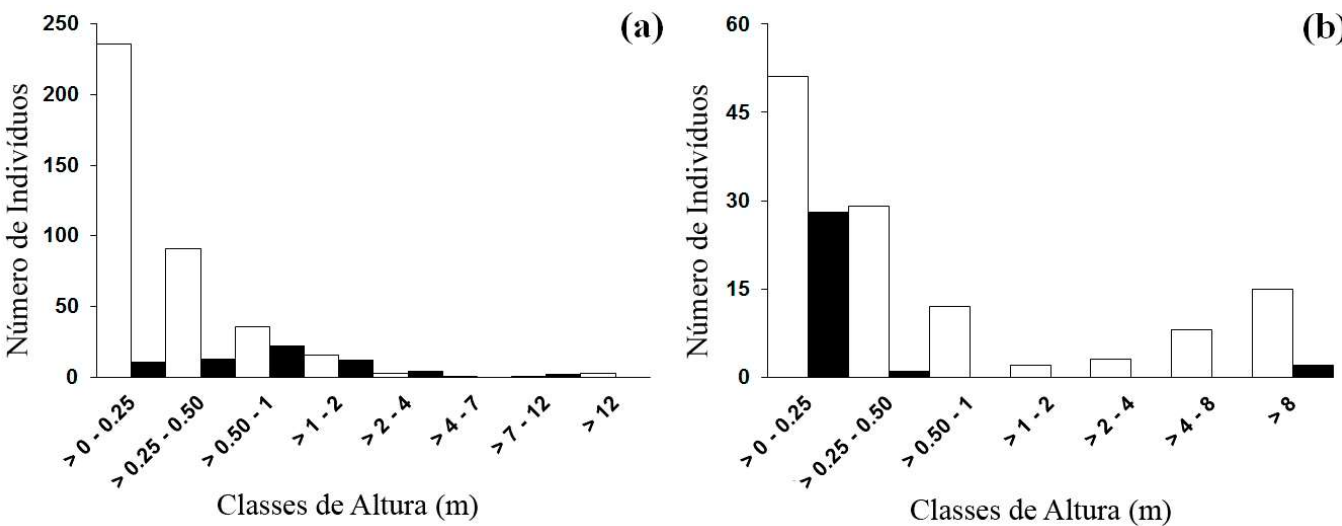

(b)

Figure 1 - Number of individuals of Astronium graveolens (a) and Gallesia integrifolia (b) in the different height classes in São Francisco Forest State Park (white bars), and the Godoy Forest State Park (black bars), Parana State, Brazil.

Figura 1 - Número de indivíduos por classes de altura das espécies intolerantes à sombra, Astronium graveolens (a) e Gallesia integrifolia (b) no Parque Estadual Mata São Francisco (barras claras), e no Parque Estadual Mata dos Godoy, Paraná, Brasil.
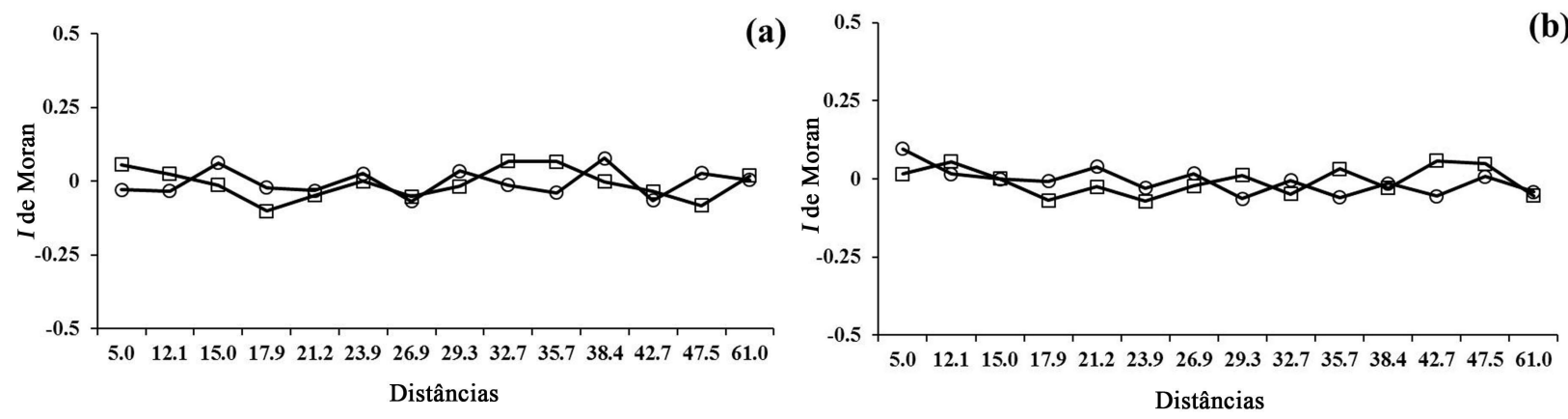

Figure 2 - Spatial correlograms of Astronium graveolens (a) and Gallesia integrifolia (b) in São Francisco Forest State Park (squares) and Godoy Forest State Park (circles), Parana State, Brazil. The correlograms were not globally significant.

Figura 2 - Correlogramas espaciais de Astronium graveolens (a) e Gallesia integrifolia (b) no Parque Estadual Mata São Francisco (quadrados) e no Parque Estadual Mata dos Godoy (círculos), Paraná, Brasil. Os correlogramas não foram globalmente significativos.

Revista Árvore, Viçosa-MG, v.40, n.3, p.395-405, 2016 
We sampled 4199 individuals of shade-tolerant species in the two areas, being 994 in SFFSP and 3205 in GFSP (Table 1). The three shade-tolerant species were more abundant in GFSP.

The height structure differed among fragments for three species (Table 1), probably related to a higher number of individuals in the first height classes in GFSP (Figure 3).

The height structure of C. gonocarpum was similar to a negative exponential pattern in both areas, being more evident in GFSP (Figure 3), due to higher number of individuals in the first height class in this area.

For E. edulis, in both fragments, we observed a predominance of individuals in the first height classes and absence or small number of individuals between 1-7 $\mathrm{m}$ of height (Figure 3 ). In SFFSP and GFSP, two and 55 individuals had height higher than $10 \mathrm{~m}$, respectively.

In GFSP, $H$. balansae showed high concentration of individuals in the first height class and notable reduction of individuals in subsequent classes. In SFFSP, the height structure was similar to the GFSP, except for the first class (Figure 3).

The spatial pattern of $C$. gonocarpum populations (correlogram globally not significant) (Figure 4) suggests randomness in both areas. Euterpe edulis population showed random distribution in SFFSP (Figure 4) and significant positive autocorrelation in GFSP (Figure 4)
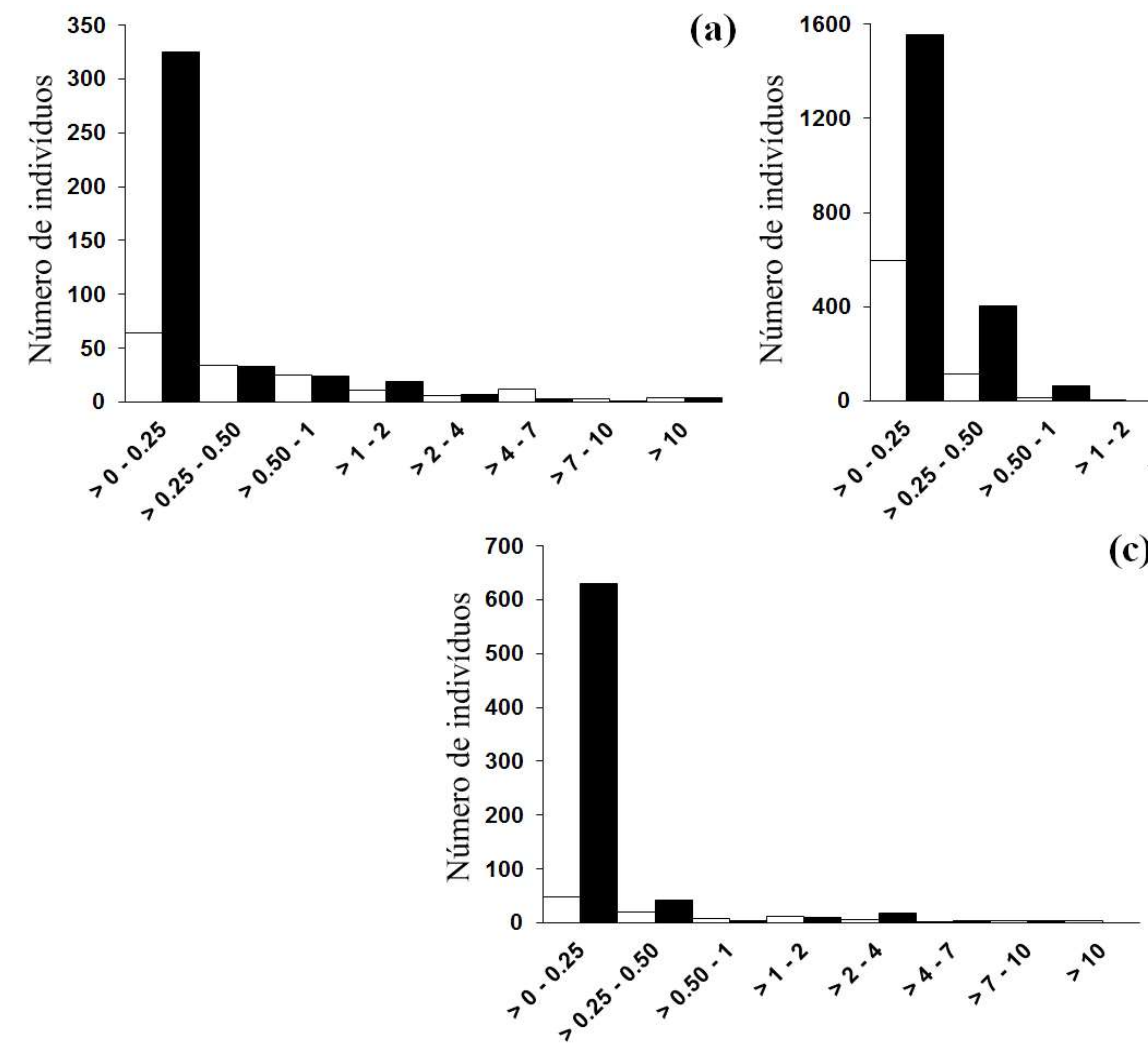

Classes de Altura (m)

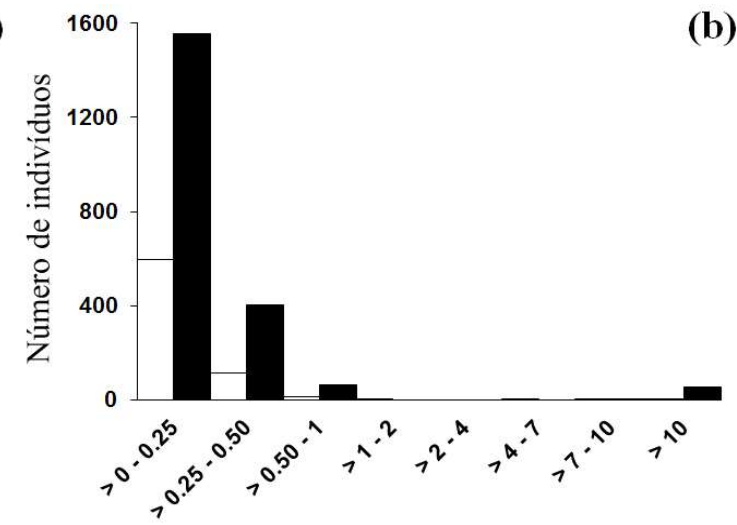

(c)

Figure 3 - Number of individuals of Chrysophyllum gonocarpum (a), Euterpe edulis (b) and Holocalyx balansae (c) in the different height classes in São Francisco Forest State Park (white bars) and the Godoy Forest State Park (black bars), Parana State, Brazil.

Figura 3 - Número de individuos por classes de altura das espécies tolerantes á sombra, Chrysophyllum gonocarpum (a), Euterpe edulis (b) and Holocalyx balansae (c), no Parque Estadual Mata São Francisco (barras claras), $e$ no Parque Estadual Mata dos Godoy, Paraná, Brasil. 

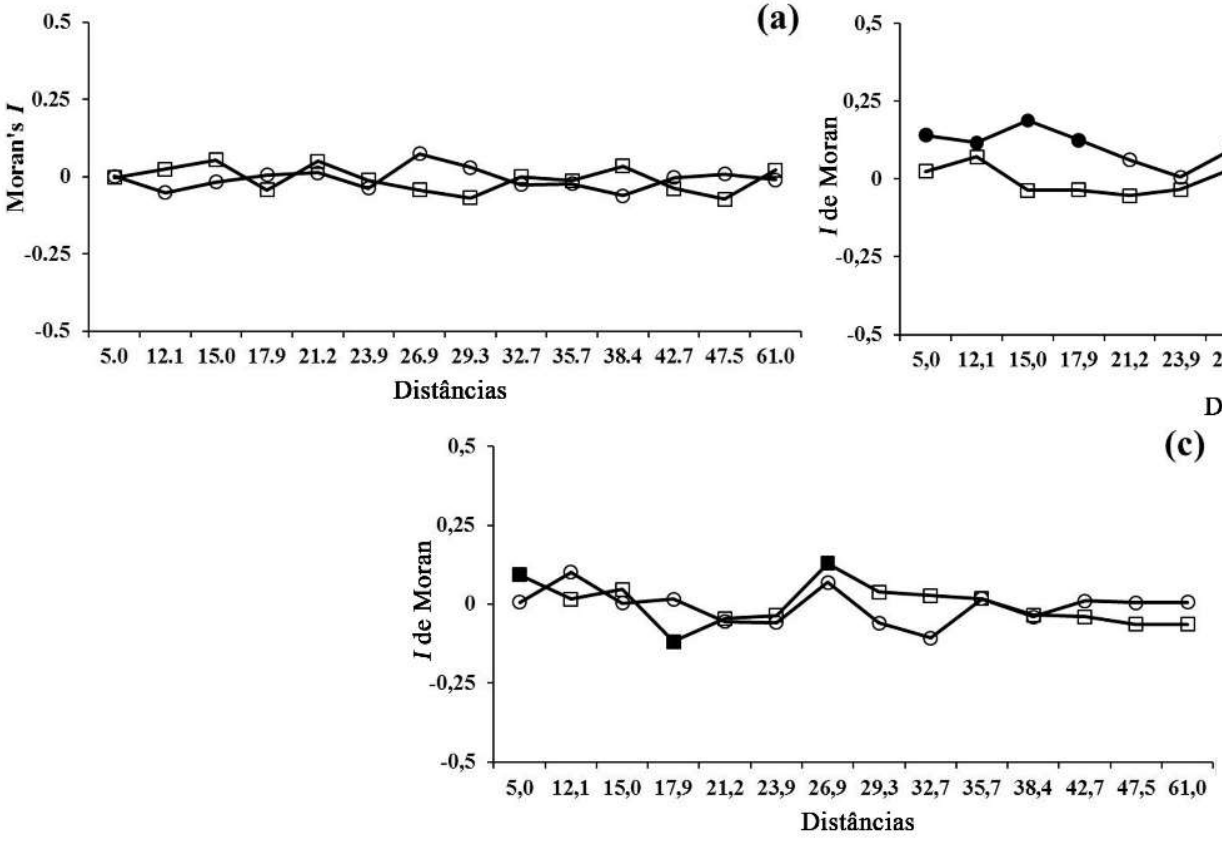

(b)

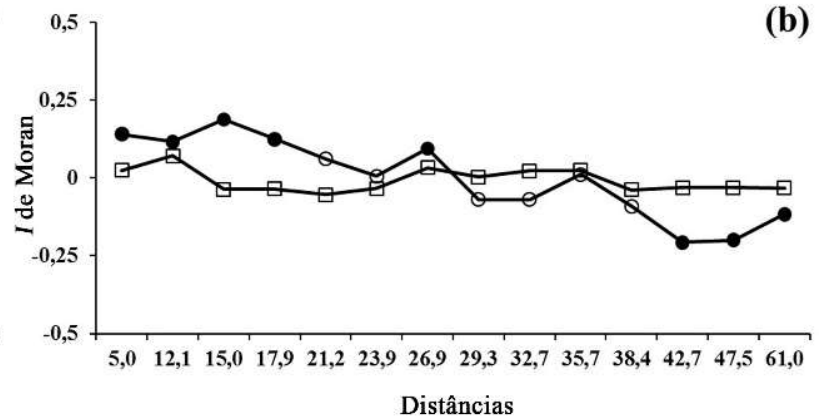

(c)

Figure 4 - Spatial correlograms of Chrysophyllum gonocarpum (a), Euterpe edulis (b) and Holocalyx balansae (c) in San Francisco Forest State Park (squares) and Godoy Forest State Park (circles), Parana State, Brazil. Black symbols indicate values of Moran's I significant at level of $\alpha=5 \%$.

Figura 4-Correlogramas espaciais de Chrysophyllum gonocarpum (a), Euterpe edulis (b) and Holocalyx balansae (c) no Parque Estadual Mata São Francisco (quadrados) e no Parque Estadual Mata dos Godoy (círculos), Paraná, Brasil. Símbolos do correlogramas preenchidos em preto indicam valores de I de Moran significativos ao nivel de $\alpha=5 \%$.

presenting clumps of ca. $18 \mathrm{~m}$, separated from each other about $10 \mathrm{~m}$

In SFFSP, $H$. balansae population had significant positive autocorrelation, showing aggregation of small clumps to $5 \mathrm{~m}$, separated from each other about $20 \mathrm{~m}$ (Figure 4), while the spatial pattern was random (correlogram globally not significant) in GFSP (Figure 4).

Spatial pattern of C. gonocarpum and H. balansae were not correlated with $\mathrm{CI}$ for both areas $(\mathrm{P}>0.05)$. In GFSP, the partial Mantel test analysis indicated a higher number of individuals of $E$. edulis in areas with higher index cover $(\mathrm{P}<0.05)$. There was not this correlation in SFFSP $(\mathrm{P}>0.05)$.

\section{DISCUSSION}

The highest number of shade-intolerant individuals found in SFFSP is characteristic of selective logging habitats (ALVES; METZGER, 2006). This occurs because selective logging creates new habitats for the shade-intolerant species, and the increased luminosity inside the forest promotes these species
(IMAI et al., 2012). On the other hand, a larger number of shade-tolerant individuals is more frequently in conserved areas because are persistent, with most of individuals surviving and growing with lower luminosity rate inside the forest (ALVES; METZGER, 2006; POORTER et al., 2008).

The anthropogenic exploitation changed environmental conditions, creating a mosaic of patches with different canopy cover and luminosity, favoring shade-intolerant and shade-tolerant species (IMAI et al., 2012).

All populations in both areas showed a predominance of individuals in the first height classes, characteristic of many tree species and often interpreted as a sign of stability and regeneration strategy (BIANCHINI et al., 2003; MARCOS; MATOS, 2003; WRIGHT et al., 2003; ALVES; METZGER, 2006; BIANCHINI et al., 2010). The selective logging and other directly or indirectly related disturbances influenced the population structure (MILIOS et al., 2007; ZIMMERMAN; KORMOS, 2012), because was a difference in the height structure and 
in abundance for all populations studied in SFFSP, when compared to GFSP.

The low number of individuals of E. edulis in the last two height classes is another evidence of human impact on SFFSP. The absence of individuals in intermediate classes for both areas was not expected, especially in GFSP. A possible explanation is predation, which was detected in GFSP. Many individuals of $E$. edulis, with height of up to $80 \mathrm{~cm}$, had leaves with open sheaths and depredated stem apex. Field observations indicated that capuchin monkeys (Cebus nigritus Goldfuss, 1809) ate apexes of these individuals. Although we did not observe it, this predation is also possibly occurring in SFFSP because the primate is one of the most abundant species in the fragment (REZENDE, unpublished data). Predation by capuchin monkeys was also found in other fragments of Atlantic Forest in southeastern of Brazil (PORTELA et al., 2010a; PORTELA et al., 2010b). According to these authors, the effects of predation by capuchin monkeys have same impact on the mortality of individuals of E. edulis than the anthropic exploitation of palm tree. These authors also related that predation of smaller individuals offers best cost/benefit relation than predation of adults, because of the higher proportion of smaller individuals. Furthermore, the absence of individuals in the intermediate classes does not mean that a population of E. edulis had a problem with recruitment. According to Wright et al. (2003), the individuals may remain in smaller classes for a long time until occurs an environmental change, such as the death of a tree, a falling tree or a branch. This environmental change increases the light levels, which can promote the accumulation of biomass and growth of individuals for the following classes.

Marcos and Matos (2003) have observed the absence of individuals of E. edulis in major classes in areas where fires and (or) selective harvest have occurred. These authors also observed the presence of smaller individuals in these areas and suggested that the regeneration process was occurring, similar to that observed in SFFSP.

The random spatial pattern of $C$. gonocarpum population was also observed in GFSP by Bianchini et al. (2003), and in another fragment of region (BIANCHINI et al., 2010). Bianchini et al. (2010) suggested that species could be a microsite generalist.
The aggregated spatial pattern of $H$. balansae in SFFSP could be explained by closely occurrence of three individuals higher than $10 \mathrm{~m}$ of height. This proximity could increase the availability of favorable microsites near of parental plant, similar to observed for Copaifera langsdorffii Desf. in a gallery forest in southeastern Brazil (RESENDE et al., 2003).

Differently from what was observed for $A$. graveolens in this study, Pavanelli et al. (2011) found aggregated spatial pattern to species with clumps of up to $8 \mathrm{~m}$ in 0.5 ha area $(50 \mathrm{~m} \times 100 \mathrm{~m})$ in GFSP and in another fragment of Seasonal Semideciduous Forest in the region $\left(23^{\circ} 16^{\prime} \mathrm{S} 51^{\circ} 01^{\prime} \mathrm{W}\right)$. Besides of selective logging of adults and different scales can explain this difference. While we analyzed $0.3 \mathrm{ha}(50 \mathrm{~m} \times 60 \mathrm{~m})$, Pavanelli et al. (2011) analyzed an area of 0.5 ha, which probably influenced the result of this study. Furthermore, we observed some patches of aggregation in SFFSP, but they were not detected probably due to the lower scale used.

The establishment of Gallesia integrifolia in SFFSP occurred in areas with higher luminosity created by selective logging, which could explain the randomness of its spatial pattern, in SFFSP. In GFSP the random spatial pattern was expected due to the highest cover index canopy, which could limit recruitment and establishment of new individuals.

The selective logging of adult plants in SFFSP could also explain the difference in E. edulis spatial pattern compared to GFSP (RONDON et al., 2012). The lower number of mature plants could have limited seed production and dispersal and altered the natural spatial pattern of this population. The higher canopy cover improved germination and establishment of individuals of this species in GFSP, similar to that found by Marcos and Matos (2003) in a conserved fragment of Atlantic forest in southeastern Brazil.

The regeneration of shade-tolerant species in SFFSP is confirmed by the presence of individuals in the first class of height and reproductive individuals. In GFSP, we also observed regeneration of shade-intolerant species, indicating the importance of spatial heterogeneity in light distribution maintained by natural dynamics of gaps, caused by breaking branches and death of adult plants, which increases richness of species within forest (LIMA, 2005; ALVES; METZGER, 2006). According to Whitmore (1991), a large number of

Revista Árvore, Viçosa-MG, v.40, n.3, p.395-405, 2016

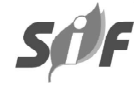


individuals in smaller height classes, for both functional groups, as observed in SFFSP, is an indicative of forest regeneration after disturbances.

The selective logging in SFFSP could explain difference in height structure for studied species and the spatial pattern of $E$. edulis. One of the main consequences of selective logging, in addition to the palm, was a decrease in canopy cover and gap formation. This process allowed for higher recruitment of shadeintolerant species. Over time, these individuals grew rapidly and promoted the canopy closes again (BROADBENT et al., 2006; CARREÑO-ROCABADO et al., 2012), reducing the number and size of gaps and, consequently, the luminosity in the understory. In this new scenario, there would be a reduction in the number of microsites favorable to the regeneration of shadeintolerant species, similar to GFSP, which is considered an old-growth forest.

\section{CONCLUSION}

This study showed that populations of five tree species were altered by selective logging and their direct and indirect consequences (human impacts). The GFSP showed characteristics of old-growth forest, demonstrated by higher number of large individuals of E. edulis, and the higher number of shade tolerant individuals compared to SFFSP. On the other hand, the SFFSP has been found in an intermediate stage of regeneration, characterized by a mosaic of vegetation in different successional stages, caused by anthropic exploitation. Due to the persistence of shade-tolerant and shade-intolerant species on SFFSP over time and the end of anthropic exploitation, probably this fragment will reach the stability of old-growth forest. However, excessive bamboos and lianas in SFFSP can prevent or delay this process.

\section{ACKNOWLEDGEMENTS}

We thank the Postgraduate Program in Biological Sciences of the State University of Londrina for the Support, The Brazilian Education Council (CAPES) and the Environmental Institute of Paraná (IAP) for authorizing the work in protected areas.

\section{REFERENCES}

AGREN, J.; ZACKRISSON, O. Age and size structure of Pinus sylvestris populations on mires in central and northern Sweden. Journal of Ecology, v.78, p.1049-1062, 1990.

ANDRADE, P.M.; SANTOS, F.A.M.; MARTINS, F.R. Size structure and fertility in an Eriocnema fulva Naudin (Melastomataceae) population in Southeastern Brazil. Brazilian Journal of Biology, v.67, p.685-693, 2007.

ALVES, L.F.; METZGER, J.P. A regeneração florestal em áreas de floresta secundária na Reserva Florestal do Morro Grande, Cotia, SP. Biota Neotropica, v.6, n.2, p.1-26, 2006.

BIANCHINI, E.; POPOLO, R.S.; DIAS, M.C.; PIMENTA, J.A. Diversidade e estrutura de espécies arbóreas em área alagável do município de Londrina, Sul do Brasil. Acta Botanica Brasilica, v. 17, p.405-419, 2003.

BIANCHINI, E.; GARCIA, C.C.; PIMENTA, J.A.; TOREZAN, J.M.D. Slope variation and population structure of trees species from different ecological groups in South Brazil. Anais da Academia Brasileira de Ciências, v.82, p.643-652, 2010.

BROADBENT, E.N.; ZARIN, D.J.; ASNER, G.P.; PEÑA-CLAROS, M.; COOPER, A.; LITTELL, R. Recovery of forest structure and spectral properties after selective logging in lowland Bolivia. Ecological Applications, v.16, p.1148-1163, 2006.

BROWER, J.E.; ZAR, J.H. Field and

laboratory methods for general ecology. Dubuque: W. M. C. Brown, 1984. 226p.

BRUNA, E.M.; KRESS, W.J. Habitat fragmentation and the demographic structure of an Amazonian understory herb (Heliconia acuminata).

Conservation Biology, v.16, p.1256-1266, 2002.

BURTON, J.I.; ZENNER, E.K.; FRELICH, L.E.; CORNETT, M.W. Patterns of plant community structure within and between primary and secondgrowth northern hardwood forest stands. Forest Ecology and Management, v.258, p.25562568, 2009.

CARREÑO-ROCABADO, G.; PEÑA-CLAROS, M.; BONGERS, F.; ALARCÓN, A.; LICONA, J. Effects of disturbance intensity on species and functional 
diversity in a tropical forest. Journal of Ecology, v.100, n.6, p.1289-1611, 2012.

DE CROP, E.; BRYS, R.; HOFFMANN, M. The impact of habitat fragmentation on the interaction between Centaurium erythraea (Gentianaceae) and its specialized seed predator Stenoptilia zophodactylus (Pterophoridae, Lepidoptera). Ecological Research v.27, p.967-974, 2012.

DIAS, M.C.; VIEIRA, A.O.S.; PAIVA, M.R.C. Florística e fitossociologia das espécies arbóreas das florestas da bacia do rio Tibagi. In: MEDRI, M.E.; BIANCHINI, E.; SHIBATTA, O.A.; PIMENTA, J.A. (Ed.). A Bacia do Rio Tibagi. Londrina: Universidade Estadual de Londrina, 2002. p.109-124

\section{EMPRESA BRASILEIRA DE PESQUISA} AGROPECUÁRIA - EMBRAPA. Sistema brasileiro de classificação levantamento de solos. Rio de Janeiro: 1999. $412 \mathrm{p}$.

GAMA, J.R.V.; BOTELHO, S.A.; BENTES-GAMA, M.M. Composição florística e Estrutura da regeneração natural de floresta secundária de Várzea Baixa no Estuário Amazônico. Revista Árvore, v.26, n.5, p.559-566, 2002.

GETZIN, S.; WIEGAND, T.; WIEGAND, K.; HE, F. Heterogeneity influences spatial patterns and demographics in forest stands. Journal of Ecology, v.96, p.807-820, 2008.

GUARIGUATA, M.R.; OSTERTAG, R. Neotropical secondary forest succession: changes in structural and functional characteristics. Forest Ecology and Management, v. 148, p. 185 206, 2001

HUTCHINGS, M.J. The structure of plant population. In: CRAWLEY, M.J. (Ed.). Plant Ecology. Oxford: Blackwell Scientific Publish, 1997. p. $97-136$

IMAI, N.; SEINO, T.; AIBA, S.; TAKYU, M.; TITIN, J.; KITAYAMA, K. Effects of selective logging on tree species diversity and composition of Bornean tropical rain forests at different spatial scales. Plant Ecology, v.213, p.1413-1424, 2012.
INSTITUTO AGRONÔMICO DO PARANÁ IAPAR . Cartas Climáticas do Estado do Paraná. 2000. Disponível em: http:// www.iapar.br. Acess in: 01/ 09/ 2008.

LEGENDRE, P.; FORTIN, M.J. Spatial pattern and ecological analysis. Vegetatio, v.80, p.107-138, 1989.

LIEBSCH, D.; MARQUES, M.C.M.; GOLDENBERG, R. How long does the Atlantic Rain Forest take to recover after a disturbance? Changes in species composition and ecological features during secondary succession. Biological

Conservation, v.141, p.1717-1725, 2008.

LEMMON, P.E. A spherical densiometer for estimating forest overstorey density. Forest Science, v.2, p.341-320, 1956.

LIMA, R.A.F. Estrutura e regeneração de clareiras em Florestas Pluviais Tropicais. Revista Brasileira de Botânica, v.28, n.4, p.651-670, 2005.

LORENZI, H. Árvores brasileiras: manual de identificação e cultivo de plantas arbóreas nativas do Brasil. 2.ed. Nova Odessa: Instituto Plantarum, 2002. v.1.384p.

MARANGON, L.C.; SOARES, J.J.; FELICIANO, A.L.P.; BRANDÃO, C.F.L.S. Regeneração natural em um fragmento de floresta estacional semidecidual em Viçosa, Minas Gerais. Revista Árvore, v.32, n.1, p.183-191, 2008.

MARCOS, C.S.; MATOS, D.M.S. Estrutura de populações de palmiteiro (Euterpe edulis Mart.) em áreas com diferentes graus de impactação na Floresta da Tijuca, RJ. Floresta e Ambiente, v.10, n.1, p.27-37, 2003.

MILIOS, E.; PIPINIS, E.; PETROU, P.; AKRITIDOU, S.; SMIRIS, P.; ASLANIDOU, $M$. Structure and regeneration patterns of the Juniperus excelsa Bieb. stands in the central part of the Nestos valley in the northeast of Greece, in the context of anthropogenic disturbances and nurse plant facilitation. Ecological Research, v.22, p.713-723, 2007.

ODEN, N.L. Assessing the significance of a spatial correlogram. Geographical Analysis, v.16, n.1, p.1-16, 1984.

Revista Árvore, Viçosa-MG, v.40, n.3, p.395-405, 2016 
PAVANELLI, A.P.; COSTA, J.A.; BIANCHINI, E.; PIMENTA, J.A. Estrutura de tamanho, relações alométricas e distribuição espacial de Astronium graveolens Jacq. (Anacardiaceae) em áreas topograficamente distintas de fragmentos de Floresta Estacional Semidecidual do Sul do Brasil. Pesquisas Botanica, v.62, p.347-363, 2011.

PORTELA, R.C.Q.; BRUNA, E.M.; SANTOS, F.A.M. Are protected areas really protecting populations? A test with an Atlantic rain forest palm. Tropical Conservation Science, v.4, p.361-372, 2010a.

PORTELA, R.C.Q.; BRUNA, E.M.; SANTOS, F.A.M. Demography of palm species in Brazil's Atlantic forest: a comparison of harvested and unharvested species using matrix models.

Biodiversity and Conservation, v.19, n.8, p.2389-2403, 2010b.

POORTER, L.; HAWTHORNE, W.; BONGERS, F.; SHEIL, D. Maximum size distributions in tropical forest communities: relationships with rainfall and disturbance. Journal of Ecology, v.96, p.495504,2008

RESENDE, J.C.F.; KLINK, C.A.; SCHIAVINI, I. Spacial heterogeneity and its influence on Copaifera langsdorffii Desf. (Caesalpiniaceae).

Brazilian Archives of Biology and Technology, v.46, p.405-414, 2003.

RONDON, X.J.; CUMMING, G.S.; COSSÍO, R.E.; SOUTHWORTH, J. The Effects of Selective Logging Behaviors on Forest Fragmentation and Recovery. International Journal of Forestry Research, v.2012, p.1-10, 2012.

ROSENBERG, M.S. PASSAGE - Pattern Analysis, Spatial Statistics, and Geographic Exegesis. Arizona: AZ, 2001.

SAHU, S.C.; DHAL, N.K.; MOHANTY, R.C. Tree species diversity, distribution and population structure in a tropical dry deciduous forest of Malyagiri hill ranges, Eastern Ghats, India.

Tropical Ecology, v.53, n.2, p.163-168, 2012.

SILVA, F.C.; SOARES-SILVA, L.H. Arboreal flora of the Godoy Forest State Park, Londrina, PR. Brazil. Edinburgh Journal of Botany, v.57, n.1, p.107-120, 2000.

Revista Árvore, Viçosa-MG, v.40, n.3, p.395-405, 2016
SILVEIRA, M.A. A vegetação do Parque Estadual Mata dos Godoy. In: TOREZAN, J.M.D. (Org.). Ecologia do Parque Estadual Mata dos Godoy. Londrina: ITEDES, 2006. p.1927

SMOUSE, P.E.; LONG, J.C.; SOKAL, R.R. Multiple regression and correlation extensions of the Mantel test of matrix correspondence.

Systematic Zoology, v.35, p.627-632, 1986.

SOARES-SILVA, L.H.; BARROSO, G.M.

Fitossociologia do estrato arbóreo da floresta na porção norte do Parque Estadual Mata dos Godoy, Londrina-PR, Brasil. In: CONGRESSO DA SOCIEDADE BOTÂNICA DE SÃO PAULO, 8., 1992, Campinas. Anais... Campinas: 2007.

SOUZA, A.F. Ecological interpretation of multiple population size structures in trees: The case of Araucaria angustifolia in South America. Austral Ecology, v.32, p.524-533, 2007.

SOUZA, A.L.; SCHETTINO, S.; JESUS, R.M.; VALE, A.B. Dinâmica da regeneração natural em uma floresta ombrófila densa secundária, após corte de cipós, Reserva Natural da Companhia Vale do Rio Doce S.A., Estado do Espírito Santo, Brasil. Revista Árvore, v.26, n.4, p.411-419, 2002.

SUZUKI, N.S.; KACHI, N.; SUZUKI, J.I. Variability of local spatial structure in a waveregenerated Abies forest. Ecological Research, v.27, p.893-901, 2012.

SWAINE, M.D.; WHITMORE, T.C. On the definition of ecological species groups in tropical rain forests. Vegetatio, v.75, p.81-86, 1988.

TABARELLI, M.; PINTO, L.P.; SILVA, J.M.C.; HIROTA, M.M.; BEDÊ, L.C. Desafios e oportunidades para a conservação da biodiversidade na Mata Atlântica brasileira. Megadiversidade, v.1, n.1, p.132-138, 2005.

TOMÉ, M.; MIGLIORANZA, E.; VILHENA, A.H.T.; FONSECA, E.P. Composição florística e fitossociológica do Parque Estadual Mata São Francisco. Revista Instituto Florestal, v.11, n.1, p.13-23, 1999. 
TSINGALIA, M. Impacts of selective logging on population structure and dynamics of a canopy tree (Olea capensis) in Kakamega forest.

African Journal of Ecology, v.48, p.569575,2010 .

WHITMORE, T.C. Tropical rain forest dynamics and its implications for management. In: GÓMEZPOMPA, A.; WHITMORE, T.C.; HADLEY, M.

(Ed.). Rain forest regeneration and management. Paris: UNESCO \& Parthenon Publications, 1991.p.67-89

WRIGHT, S.J.; MULLER-LANDAU, H.C.; CONDIT, R.; HUBBELL, S.P. Gap-dependent recruitment, realized vital rates, and size distributions of tropical trees. Ecology, v. 84, p.3174-3185, 2003.

ZAMA, M.Y.; BOVOLENTA, Y.R.; CARVALHO, E.S.; RODRIGUES, D.R.; ARAUJO, C.G.; SORACE, M.A.F.; LUZ, D.G. Florística e síndromes de dispersão de espécies arbustivo-arbóreas no Parque Estadual Mata São Francisco, PR, Brasil. Hoehnea, v.39, p.369-378, 2012.

ZAR, J.H. Biostatistical analysis. New Jersey: Prentice-Hall, 1996.

ZIMMERMAN, B.L.; KORMOS, C.F. Prospects for Sustainable Logging in Tropical Forests. Bioscience, v.62, p.479-487, 2012. 